\title{
Ecological Study on Arthritica reikoae (Bivalvia: Cardiida), the Dominant Microbivalve in the Inner Tidal Flats of Tokyo Bay, Japan.
}

\author{
景山良祐 ${ }^{1)}$ ・ 碓水裕史 ${ }^{2 ｝ \text { ・ 早瀬善正 }{ }^{3)} \text { ・西村 } \text { 修 }^{2)} \text { ・ 中瀬浩太 }{ }^{4 ）} \text {-木村賢史 }{ }^{5), *}$ \\ 1) 東海大学大学院海洋学研究科水産学専攻. T424-8610 静岡県静岡市清水区折戸 3-20-1 \\ 2) 東北大学大学院工学研究科土木工学専攻. $\overline{7} 980-8579$ 宮城県仙台市青葉区荒巻字青葉 6-6-06 \\ 3）株式会社東海アクアノーツ。广424-0023 静岡県静岡市清水区八坂北 1-10-12 \\ 4) 五洋建設株式会社環境事業部。 $\bar{T} 112-8576$ 東京都文京区後楽 2-2-8 \\ 5) 東海大学海洋学部海洋生物学科. $\bar{T} 424-8610$ 静岡県静岡市清水区折戸 3-20-1
}

Ryosuke KAGEYAMA ${ }^{1}$, Hiroshi USUI $^{2)}$, Yoshimasa HAYASE ${ }^{3)}$, Kouta NAKASE ${ }^{4}$, Osamu NISHIMURA ${ }^{2)}$ and Kenshi KIMURA ${ }^{5), *}$

1) Department of Marine Biology, Graduate School of Marine Science and Technology, Tokai University, 3-20-1 Orido, Shimizu, Shizuoka 424-8610, Japan

2) Department of Civil Engineering, Graduate School of Engineering, Tohoku University, 6-6-06 Aoba, Sendai 980-8579, Japan

3) Tokai Aquanauts, Inc., 1-10-12 Yasakakita, Shimizu, Shizuoka 424-0023, Japan

4) Penta-Ocean Construction Co., Ltd., 2-2-8 Koraku, Bunkyo, Tokyo 112-8576, Japan

5) Department of Marine Biology, School of Marine Science and Technology, Tokai University, 3-20-1 Orido, Shimizu, Shizuoka 424-8610, Japan

\begin{abstract}
Arthritica reikoae (Suzuki \& Kosuge 2010) is an ovoviviparous microbivalve inhabiting estuarine tidal flats in inner bays in Japan. Although A. reikoae is the dominant bivalve species in the tidal flats, its ecological characteristics remain largely unknown. We conducted ecological studies of populations in Tokyo Bay. The field research revealed that in the summer of 2010 , more than $90 \%$ of adult $A$. reikoae bred as females. This species might be hermaphroditic similar to other congeneric species. Mature A. reikoae held 13.0 \pm 5.7 (Mean \pm S.D.) shelled larvae, and the shell length of the larvae just before release was about $0.3 \mathrm{~mm}$. The breeding cycle was estimated to be 20 days based on laboratory culturing. A reikoae produces large benthic larvae with limited dispersal but high survival. $A$. reikoae inhabits estuaries and brackish lakes where it may be exposed to a wide range of salinity. The results of a salinity tolerance experiment indicated that $A$. reikoae is euryhaline, which lets it inhabit such environments. The population density significantly increased through the breeding season, and the maximum density reached $1,578.4$ indiv. $/ 100 \mathrm{~cm}^{2}$ in the estuary of the Tama River.
\end{abstract}

Key Words: Arthritica reikoae, ecology, microbivalve, reproductive biology, tidal flat, Tokyo Bay

\section{はじめに}

ガタヅキ（コハギガイ）Arthritica reikoaeは，ガンヅキ 科 Leptonidae（近年ウロコガイ科 Galeommatidaeに統一す る見解も示されている; 日本ベントス学会 2012,p. 265） に属し, 殼長は最大でも $1.5 \mathrm{~mm}$ 程度の極めて小型の二枚 貝である。本種は江戸川放水路をタイプ産地とし，チリハ ギ属Lasaeaのコハギガイ Lasaea reikoae として記載された

Received 27 November 2012 Accepted 5 March 2013

* Corresponding author

E-mail: kenshi@scc.u-tokai.ac.jp
が (Suzuki \& Kosuge 2010), のちにガンヅキ属 Arthritica に変更された（日本ベントス学会 2012, p. 154）. ガタヅキ という和名は宮城県石巻市の長面浦より未記載種 (Arthritica sp.）として本種が見出された際に提唱された（佐藤ら 2010). 現在までにガンヅキ属には, 本邦産のガタヅキ, ガンヅキA. japonica のほか, オセアニアを原産とする A. semen, A. bifurca, A. crassiformis, A. hulmei を含めた 6 種が 知られているが, これらのうちガンヅキ, A. bifurca, A. crassiformis, A. hulmei の 4 種は種特有の共生対象を持ち, この共生種を多く含むという点は本属の目立った特徴と なっている（Ponder 1965; Chanley \& Chanley 1980; Lützen \& Takahashi 2003).しかしながらガタッ゙キは，これまでに 
分布や分類に関して若干の知見があるのみで（日本ベント ス学会 2012, p. 154), その生態の大部分は未解明である. 著者らが実施している東京湾内の人工干潟におけるベント スのモニタリング調査では, 2009 年ごろからガタッ゙キの 生息が確認されるようになり，翌年の 2010 年には生息数 が急激に増加し，2011 年の干潟修復工事により激減する ことが確認された（未発表）。そのため，本種の生息状況 や繁殖行動などの生態の詳細な把握は重要な課題である. さらに，ガタッ゙キは環境省第 4 次レッドリスト（環境省 2012）に評価 DD（情報不足）として記載され，今後の本 種の希少性の評価を行う上でも多面的な情報の蓄積が求め られる。本研究では，これまで明らかでなかったガタヅキ の生態に関して特異な繁殖生態などの新たな知見を得たの で報告する。

\section{材料と方法}

\section{調査地の概要および調査期間}

調査は，いずれも東京湾奥に位置する東京都大田区立大 森ろるさとの浜辺公園（以下大森と呼称）内の造成海域 $\left(35^{\circ} 34^{\prime} \mathrm{N}, 139^{\circ} 44^{\prime} \mathrm{E}\right)$, 江戸川放水路 ( $\left.35^{\circ} 41^{\prime} \mathrm{N}, 139^{\circ} 56^{\prime} \mathrm{E}\right)$, 多摩川河口域 $\left(35^{\circ} 32^{\prime} \mathrm{N}, 139^{\circ} 46^{\prime} \mathrm{E}\right)$ の河口から約 $3 \mathrm{~km}$ 上
流までの干潟上で行った（Fig. 1a）.

大森の造成海域には, 海浜部 (1.2 ha) ・ 干潟部 (1.0 ha) • 浅場部（4.6 ha）が併設され，周辺は水深 4 $5 \mathrm{~m}$ 程度の運 河に囲まれている（Fig. 1b）。干潟部は同海域に存在した 波除堤（延長約 $400 \mathrm{~m}$ ）の周囲に形成されていた約 1.0 ha の天然干潟を，岸から約 $200 \mathrm{~m}$ の位置に新たに建設され た護岸（延長約 $300 \mathrm{~m}$ ）に移設する形で造成された。海浜 部と浅場部は千葉県君津産の山砂（中央粒径, $\mathrm{d}_{50}=$ $0.2 \mathrm{~mm}$ ）によって造成され, 海浜部の A.P. $+1.0 \mathrm{~m}$ より地 盤の高い部分には周辺への飛砂防止のために香川県小豆島 産の碟（ $\left.\mathrm{d}_{50}=4.0 \mathrm{~mm}\right)$ が散布された。干潟部は 2002 年に 移設工事が完了し，海浜部と浅場部については 2004 年に 完成した。 2007 年 3 月には海浜部，また 2011 年 2 月には 干潟部と浅場部を対象に，地形改変や砂泥を補充する目的 で千葉県君津産の山砂が追加覆砂された。

江戸川放水路は 1919 年に治水目的で開削された人工河 川で，1957 年には開削以前の本流である旧江戸川との分 岐部から $500 \mathrm{~m}$ 程度下流に可動堰が建設された。通常時, 可動堰は締め切られ，放水路内は東京湾から潮汐に伴い海 水が流出入する「入り江」のような構造となっている. 可 動堰は年に 1〜2 回の頻度で上流の増水時に開放され, 放 水路の環境を大きく攪乱する。最近では 2011 年 9 月の台

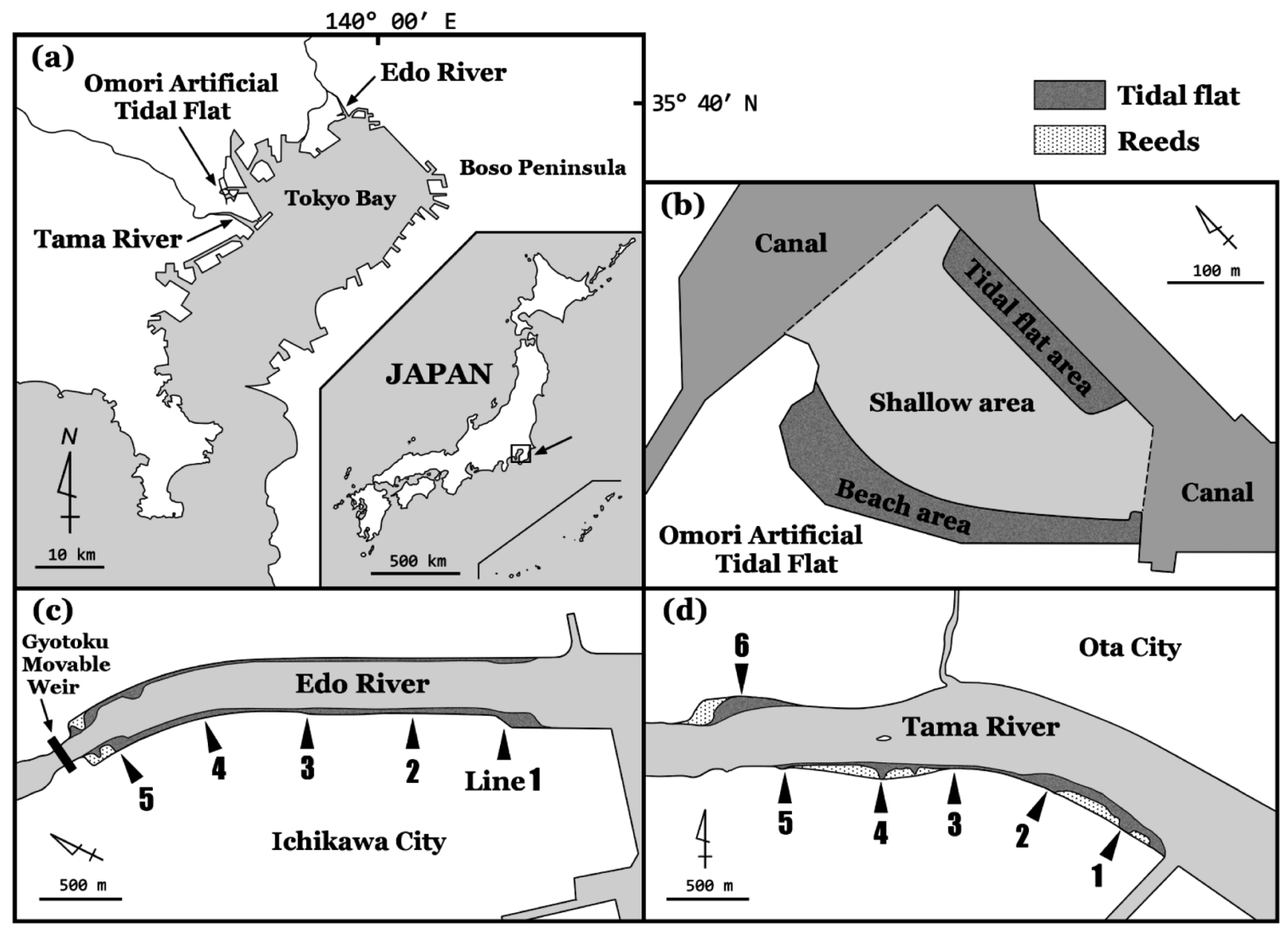

Fig. 1. Maps showing the study area in Tokyo Bay, a : positional relationship of each study sites (Omori Artificial Tidal Flat, the Edo and Tama River Estuary), b: Omori Artificial Tidal Flat, c: Edo River Estuary, d: Tama River Estuary. 
風接近に伴う出水時を最後に, 本研究の終了まで可動堰は 解放されていない. 江戸川放水路には, 可動堰直下に比較 的大きなヨシ群落を伴う干潟が干出し, 放水路中央から河 口付近にかけてヨシ群落はあまり発達せず干潟の干出幅も 狭いが, 河口付近には比較的干出幅のある干潟が出現する (Fig. 1c).

多摩川河口域の調査範囲内には, 河口部から約 $2.5 \mathrm{~km}$ 上流までの右岸, 河口から約 $3 \mathrm{~km}$ 上流の左岸にヨシ群落 を伴う河口干潟が発達する（Fig. 1d）。多摩川には, 河川 の流れを妨げるような構造物はなく, 可動堰の存在する江 戸川よりも平時の河川水流下や増水による攪乱の影響を強 く受ける。

調査は, 大森では 2010 年 6 月から 2011 年 5 月, 江戸川 と多摩川では 2011 年 12 月から 2012 年 10 月にかけて, い ずれも大潮の昼の干潮時に実施した。

\section{繁殖生態に関する検討方法}

ガタッ゙キの殼内で保育中の卵や胎貝は，ピンセット等を 用いて親貝の殼を破壊することで比較的容易に観察するこ とができる，そこで, 本種の詳細な繁殖生態の把握を目的 として, 成貝の体内の卵および胎貝の保有状況について経 時的な変化を調査した。この観察に際しては, 殼長が $1.2 \mathrm{~mm}$ 以上の個体を成貝とした. 成貝の基準については, 殸長 $1 \mathrm{~mm}$ を超えた個体が卯の保有を始めることから, 確 実な卵保有が期待できる $1.2 \mathrm{~mm}$ に設定した。

\section{（1）野外における繁殖生態調査方法}

2010 年 6 月から 2011 年 5 月にかけて, 大森の個体群を 対象に卵および胎貝の保有状況を調査した。ガタッ゙キは $0.5 \mathrm{~mm}$ の篩を用いて 2010 年 6, 8, 9, 10, 11 月, 2011 年 1, 2, 4,5 月の各月 1 回採集し, $10 \%$ ホルマリンで固定して研究 室に持ち帰った。 2010 年 6, 8, 9, 11 月, 2011 年 2, 4, 5 月は 同時に採集地直近の表層海水温を測定した。この調査で は, 得られた個体から成貝のみを抽出し, 各月 100 個体を 上限に体内の卵と胎貝の保有状況を調べ, 胎貝を保有する 場合は保有数を計数した.

\section{（2）飼育下での繁殖生態に関する検討方法}

夏場を想定した加温条件下で繁殖休止期の個体を飼育 し, 飼育個体の繁殖活動がどのように進行するかを調べ た. 供試個体は 2012 年 1 月 28 日に江戸川放水路で採集し た。得られた個体は生かしたまま実験室に持ち帰り, 容量 $3 \mathrm{~L}$ のプラスチック製容器に収容した. 容器には現地の砂 泥を約 $2 \mathrm{~cm}$ の厚さで敷き, 塩分 25 に調整した人工海水を 満たした上で, 水中ポンプ（流量 $3.5 \mathrm{~L} /$ 分）により水流の 発生とエアレーションを施した。飼育水は汲み置いた水道 水で人工海水を調整し, 3 日に 1 回は全量の $1 / 3$ 程度を交 換した。これらの飼育設備は低温インキュベーター（SUM1331, SHIBATA）内に設置して適時水温を調節した. 飼育 水温は初期值を採集時の水温に近い $10^{\circ} \mathrm{C}$ に設定し, 馴致 期間として 1 月 29 日から毎日 $2^{\circ} \mathrm{C}$ 毎に段階的に水温を上
昇させ，2月 7 日から実験終了までの 42 日間は野外にお ける夏場の水温を想定した $28^{\circ} \mathrm{C}$ の恒温条件で飼育を行っ た。また, あらかじめ採取しておいた現地の砂泥を冷凍保 存しておき, 毎日一定量容器内の砂泥と入れ換えた.この 処理は, 砂泥由来の有機物を容器内に供給し, 水流により 懸濁させることで飼育個体への給餌の代用となるよう行っ たものである．実験では，2月8日から 3 月 19 日にかけ て, 毎日飼育容器からガタッ゙キの成貝 $10 \sim 13$ 個体取り出 して $10 \%$ ホルマリンで固定し, 体内の卵および胎貝の保 有状況を調べた.

\section{河口域における分布調査方法}

野外でのガタヅキの生息実態を把握する目的で, 江戸川 放水路と多摩川河口域を対象とした分布調査を行った。ま ず，護岸あるいはヨシ群落の前面に干出した干潟上に河川 流と垂直方向の調査ラインを, 江戸川に 5 カ所, 多摩川に 6 カ所設定した (Fig. 1c, d). 各ラインの河口からの距離 は, 調查後に地図上の距離と縮尺率から算出した。調査は 各ライン上に 5 $20 \mathrm{~m}$ 間隔で 2 5 カ所の地点を設け, 2012 年 6,7 月の夏期と, 9, 10 月の秋期の計 2 回実施した. 各地点では, 内径 $8.5 \mathrm{~cm}$ の円柱を用いて表層より $2 \mathrm{~cm}$ 深 までの底泥を 3 回採取し(約 $170 \mathrm{~cm}^{2}$ ), $0.5 \mathrm{~mm}$ 目の篩に かけたのち残存物を $10 \%$ ホルマリンで固定し持ち帰った。 後日, 得られたサンプルからすべてのガタヅキを拾い上 げ, 個体数を計数し, $100 \mathrm{~cm}^{2}$ あたりの換算值として各地 点の生息密度を算出した。個体の生存確認として, 殸に透 明感がある若齢個体に関しては, 殼の外から軟体部の有無 を確認し, また, 加齢や殼の污れ等で同様の方法での確認 が困難であった場合は, 殼をピンセットで割り軟体部が存 在することを確かめた。野外調査では, 同時に環境調査と して各地点の底泥を $100 \mathrm{ml}$ 持ち帰り, 強熱減量, 酸揮発 性硫化物量, シルト・クレイ含有率を調べた。また, 各ラ インの延長線上の河川表層水の水温, 塩分, $\mathrm{DO}, \mathrm{pH}$ を多 項目水質計 $(650 \mathrm{MDS}+600 \mathrm{QS}$, YSI Nanotech Inc.) を用い て調べた.

\section{塩分耐性実験方法}

塩分 $0,1,3,5,10,20,30$ の異なる 7 つの条件下での塩分 而性実験を 2011 年 12 月 1 日から 12 月 30 日にかけての 30 日間行った。実験には, 2011 年 11 月 13 日に多摩川で 採集し, 実験開始まで現地の底泥と海水中で飼育した個体 を使用した。各塩分の人工海水を満たした内径 $8.5 \mathrm{~cm}$ の シャーレにガタヅキを 20 個体収容し, インキュベーター （SUM-1331, SHIBATA）を用いて採集時の野外水温に近い $20^{\circ} \mathrm{C}$ の恒温条件で実験を行った。シャーレには完全に密閉 しない程度の蓋をすることで, 実験中の飼育水の蒸発を防 止し, 飼育水の塩分に変化が生じないよう配慮した。飼育 水は汲み置いた水道水と人工海水を用いて調整し, 2 日に 1 回は全量の $1 / 3$ 程度を交換した。個体の生存確認は, 毎 
日正午に開殼あるいは軟体部の露出がみられる個体につい て針先で刺激を与え，その際に反応を示したかどうかで 行った。 なお，閉款状態の個体については生存しているも のとして判断した。

\section{結 果}

\section{野外における繁殖生態調査}

成貝体内にみられる卵の発育ステージは, 直径が 0.05 $0.3 \mathrm{~mm}$ 程度である「卵 (eggs)」と, 薄質の原款（prodissoconch）が形成されはじめてから壳長約 $0.3 \mathrm{~mm}$ の D 型幼 生（D-shaped larvae）となるまでの「胎貝（shelled larvae）」 とに大別可能であった（Fig. 2)。なお，ここでいう「卵」 には成長途上の小型の卵から，発生開始直後の原殼を伴わ ない受精卵までが含まれており，卵径や形状，あるいは保 育形態に差異がみられるが，本研究ではそれらを区別しな かった．親貝 1 個体内に確認された胎貝数は, $13.0 \pm 5.7$ 個体（Mean \pm S.D.; $n=148 ） て ゙ あ り ，$ 最大で 29 個体の胎 貝が 1 個体の成貝中に保育されていた。また，胎貝を保有 する個体の中には, Fig. 2a のように新たな卵の形成が認 められる場合もあった。このように，親貝内に世代の異な る卵と胎貝が同時期に存在することはあったが，同一世代 の卵塊あるいは胎貝の間には目立った発育状況の差異は認 められなかった。

大森の個体群における卵・胎貝保有率と周辺海水温の変 動を Fig. 3 に示した。卵・胎貝保有率は夏場を中心に高く なり，冬場に低下するという季節的な変動が認められ，水 温変動との高い相関が得られた $(r=0.928)$. 特に, 水温 が $25^{\circ} \mathrm{C}$ をまわった 2010 年 $6,8,9$ 月に最も繁殖は活発 で，その際の卵・胎貝保有率は $90 \%$ 前後と極めて高い值
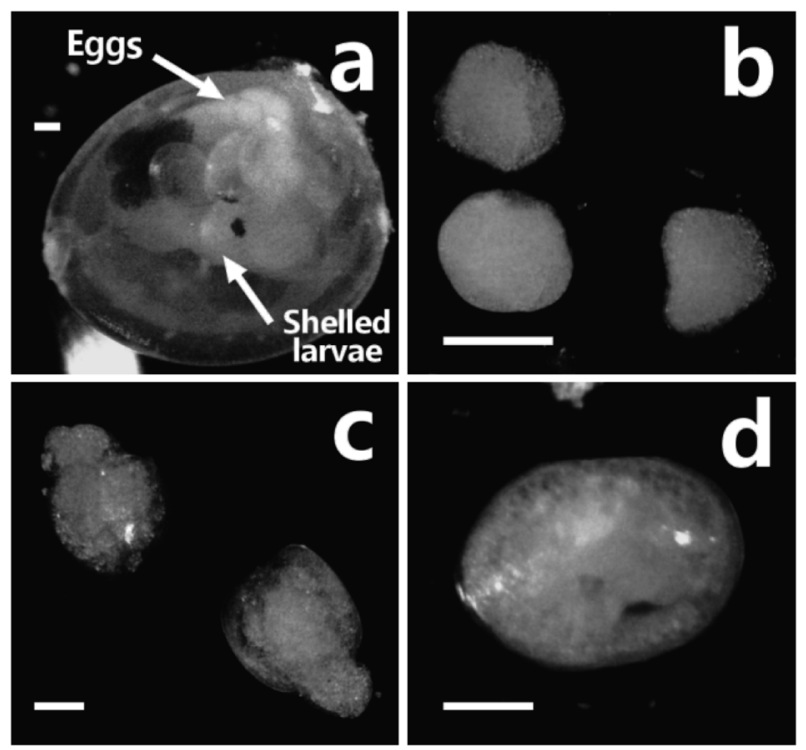

Fig. 2. Developmental stage. a : Individual carrying eggs and shelled larvae, b: Eggs, c: Immature shelled larvae, d: Shelled larvae (D-shaped larvae). White bar indicates $0.1 \mathrm{~mm}$.
を示した。さらにこの時期には，Fig. 2aのような卵と胎 貝の双方を保有する個体が全体の 14 25\%程度と比較的 高い割合で存在していた。 それに対して，冬場の 2011 年 1, 2 月になると卵や胎貝を保有する個体はほとんど出現し なくなり，この時期は繁殖に関して明らかな休止時期と なっていた。しかし，水温が $20^{\circ} \mathrm{C}$ 程度まで上昇する 4,5 月になると，卵・胎貝保有率は上昇に転じ，5月の段階で は約半数の個体に卵ないし胎貝の保有が認められた。な お，2011 年 4 月， 5 月は採集地での個体数の減少により得 られたサンプル数が少なく，観察に供することのできた個 体数は 4 月が 72 個体, 5 月が 29 個体にとどまった.

\section{飼育下での繁殖生態に関する検討}

夏場の高水温が本種の繁殖期を誘導することを明らかと するため，繁殖休止期の個体を $10^{\circ} \mathrm{C} ら 28^{\circ} \mathrm{C}$ まで段階的 に加温飼育した際にみられた卵・胎貝保育率の経日変化を Fig. 4 に示した。ここでは，卵が形成されてから成長した 胎貝が親貝の殼外へ放出されるまでの期間を明確にするた めに, 放出間際と考えられる D型幼生については発育途 上の胎貝とは区別して表記した（Fig. 4，黒塗部)。卵を保 有する個体は $28^{\circ} \mathrm{C}$ の恒温飼育を開始して 12 日目にはじめ て 1 個体が確認された。その後, 卵保有個体の割合は14 20 日後にかけて徐々に上昇し，高い時には約 $80 \%$ の個体 に卵保有が認められた。2 5 日目には表面に薄い原殼の形 成が認められる胎貝を保有する個体が 1 個体確認された. 32 日目には D 型幼生を保有する個体が 2 個体確認された. また，胎貝を保有する個体には同時に新たな卵塊の保有が みられる場合があり，D型幼生の保有が確認された 25 個 体のうち 16 個体がこうした卵塊を保有していた（Fig. 4, 下図)。実験終盤の卵と胎貝の保有割合は，大森における 野外調査の結果と同程度の約 70〜 $100 \%$ となった。このよ うに，特にエネルギーを多く必要とする繁殖活動がみられ たことは，飼育環境下における給餌等の実験条件がガタッ゙
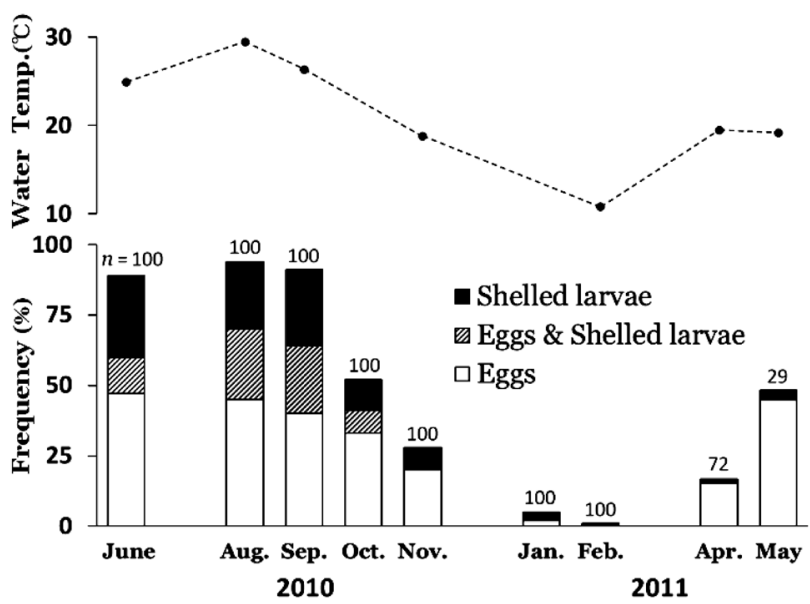

Fig. 3. Seasonal changes of the percentage of mature A. reikoae that had eggs and shelled larvae, with surface temperature at the Omori Artificial Tidal Flat, during June 2010 to May 2011. 


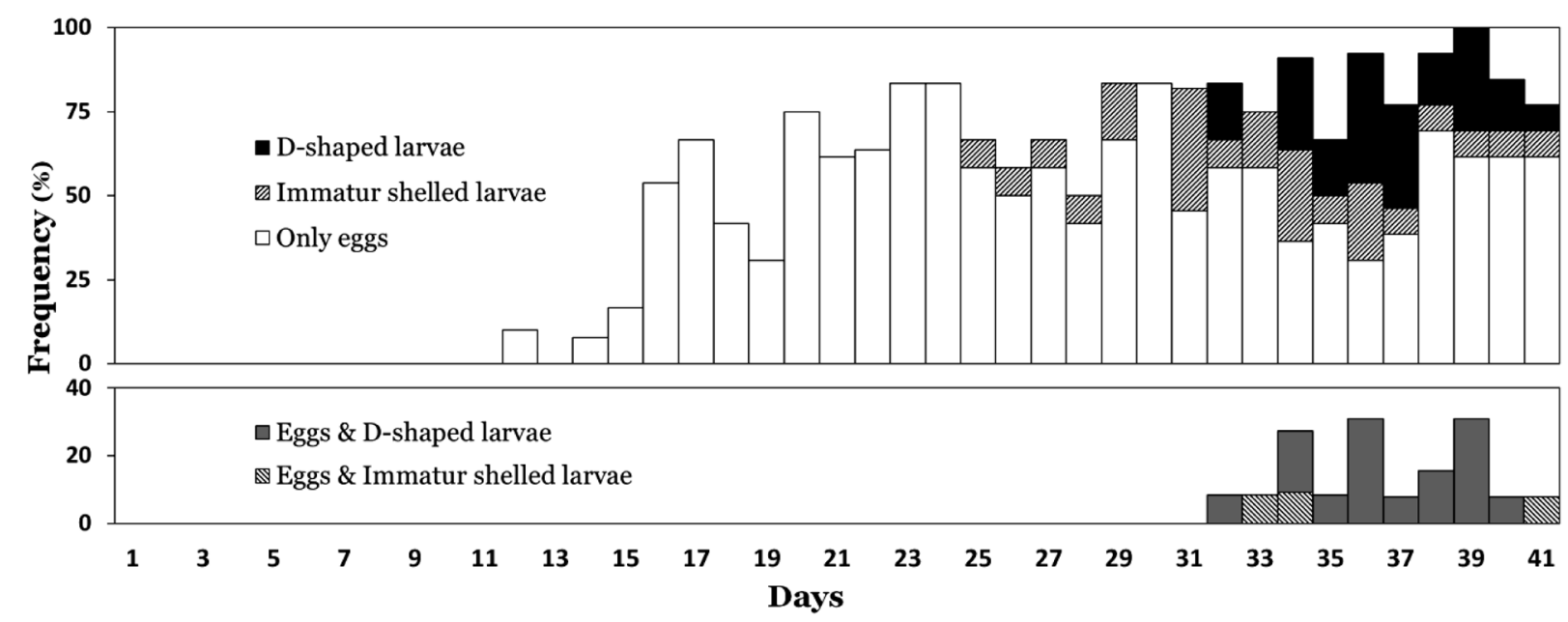

Fig. 4. Daily changes of the ratio of mature $A$. reikoae that had eggs and shelled larvae under captivity $(n=10-13$, respectively; total 497 indiv.) at $28^{\circ} \mathrm{C}$. Black bar indicates D-shaped larvae that might have been about to be released.

Edo River
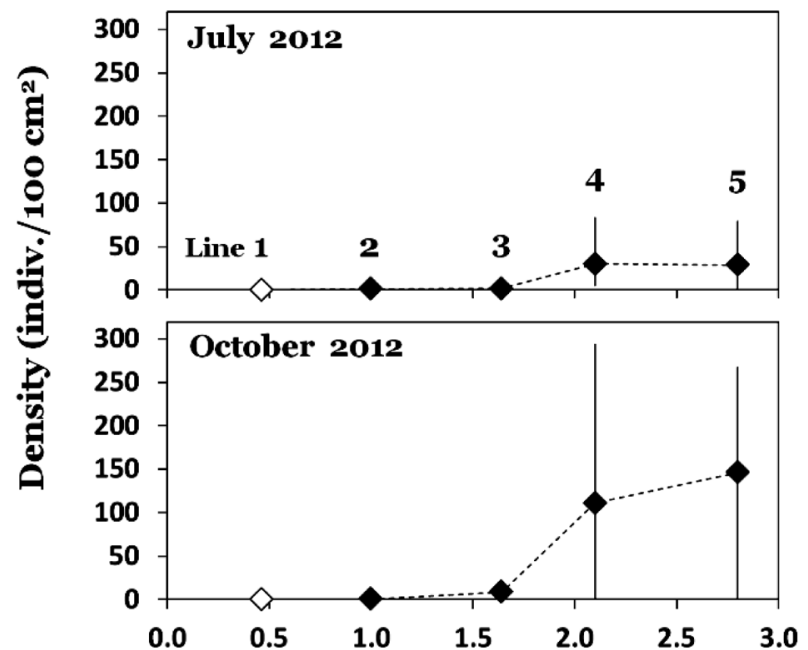

Tama River
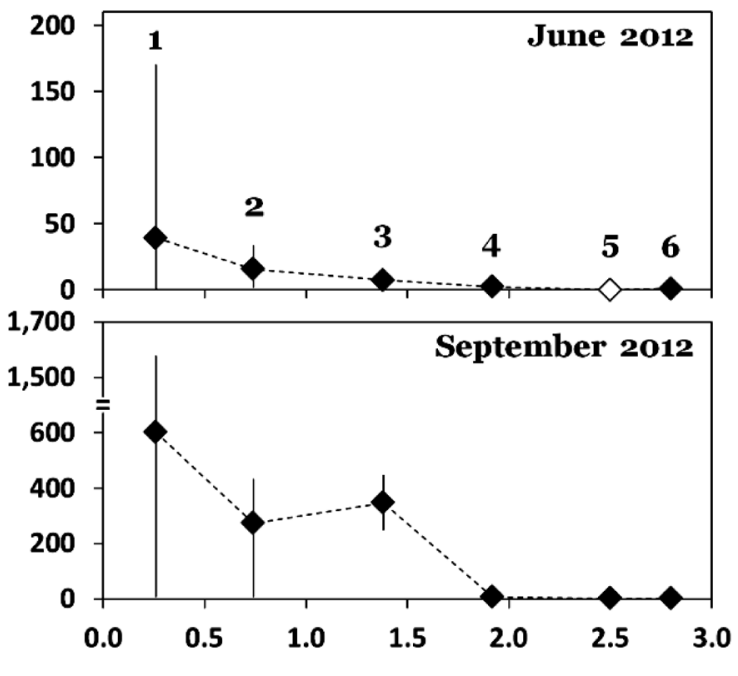

Distance from river mouth $(\mathbf{k m})$

Fig. 5. Distance from river mouth, and density of A. reikoae on each census line in the estuaries of the Edo River and the Tama River in JuneJuly and September-October in 2012. Vertical bar indicates range, white marker $(\diamond)$ indicates no individual.

キの繁殖活動の大きな支障とはならず, 自然条件下と同様 の繁殖活動が再現されているとみなされる.

\section{河口域における分布状況と生息環境}

河口域に扔いて, 夏期 (6,7月) と秋期（9,10月）に実 施したガタヅキの水平分布調査結果を Fig. 5 に示した. 江 戸川では計 2 回実施したいずれの調査においても, ライン 1 を除くすべての調査ライン上でガタヅキの生息が確認さ れ, 生息密度は可動堰に近いライン 4 とライン 5 で高くな る傾向が認められた。この両ラインの生息密度の最大值 は, 夏期に 79.9 $84.0 \mathrm{indv} .100 \mathrm{~cm}^{2}$ であったものが, 秋期 になると 267.3〜294.3 indv. $/ 100 \mathrm{~cm}^{2}$ まで増加していた。一
方多摩川では，江戸川とは異なり河口付近のライン 1〜3 に生息が集中する傾向がみられた．多摩川のライン $4 \sim 6$ では，夏期のライン 5 を除き生息個体が確認されたが，そ の数は極めて少数であった．江戸川と同様に多摩川でも， 夏期から秋期にかけて生息密度の増加が確認された。特に ライン 1 では, 夏期に最大で 170.4 indiv. $/ 100 \mathrm{~cm}^{2}$ であった 生息密度が秋期には $1,578.4$ indiv. $/ 100 \mathrm{~cm}^{2}$ となり大幅な増 加が認められた。

同時に実施した環境調査結果を Table 1 に示した。底質 のシルト・クレイ含有率は, 両河川とも河口から上流に向 かうに従い増加する傾向を示した。江戸川は，ライン 2 よ り下流はシルト・クレイ分が $30 \%$ 以下の砂質〜砂泥質の 
Table 1. Silt-clay content and salinity along each census line in the estuaries of the Edo River and the Tama River in June-July and SeptemberOctober 2012.

\begin{tabular}{|c|c|c|c|c|c|c|c|c|}
\hline \multirow{3}{*}{$\mathrm{Si}$} & & \multirow{3}{*}{$\begin{array}{l}\text { Distance from } \\
\text { river mouth } \\
\quad(\mathrm{km})\end{array}$} & \multicolumn{3}{|c|}{ JUNE-JULY 2012} & \multicolumn{3}{|c|}{ SEPTEMBER-OCTOBER 2012} \\
\hline & & & \multicolumn{2}{|c|}{ Silt-Clay（\%) } & \multirow{2}{*}{ Salinity } & \multicolumn{2}{|c|}{ Silt-Clay（\%) } & \multirow{2}{*}{ Salinity } \\
\hline & & & Mean & Range & & Mean & Range & \\
\hline \multirow[t]{5}{*}{ Edo River } & Line 1 & 0.5 & 12.5 & $7.1-16.5$ & 29.2 & 18.9 & $14.3-26.6$ & 26.6 \\
\hline & Line 2 & 1.0 & 19.8 & $15.9-23.6$ & 28.8 & 9.4 & $0.5-16.0$ & 27.8 \\
\hline & Line 3 & 1.6 & 26.0 & $5.5-41.2$ & 29.2 & 21.8 & $12.0-27.7$ & 28.4 \\
\hline & Line 4 & 2.1 & 37.1 & $16.6-50.3$ & 29.0 & 23.3 & $6.1-34.8$ & 28.2 \\
\hline & Line 5 & 2.8 & 27.4 & $10.1-45.0$ & 26.6 & 25.3 & $16.3-31.2$ & 25.9 \\
\hline \multirow[t]{6}{*}{ Tama River } & Line 1 & 0.3 & 6.5 & $1.5-19.6$ & 16.9 & 7.2 & $0.8-23.1$ & 12.7 \\
\hline & Line 2 & 0.7 & 8.0 & $4.5-12.5$ & 18.7 & 14.8 & $9.0-24.3$ & 11.7 \\
\hline & Line 3 & 1.4 & 18.1 & $9.3-26.9$ & 21.6 & 22.7 & $19.2-26.3$ & 9.6 \\
\hline & Line 4 & 1.9 & 62.1 & $44.7-73.1$ & 15.8 & 53.5 & $31.3-69.2$ & 9.0 \\
\hline & Line 5 & 2.5 & 40.0 & $9.8-70.2$ & 11.9 & 46.2 & $28.9-63.5$ & 7.7 \\
\hline & Line 6 & 2.8 & 25.7 & $1.9-63.0$ & 8.7 & 61.2 & $42.3-78.2$ & 9.9 \\
\hline
\end{tabular}

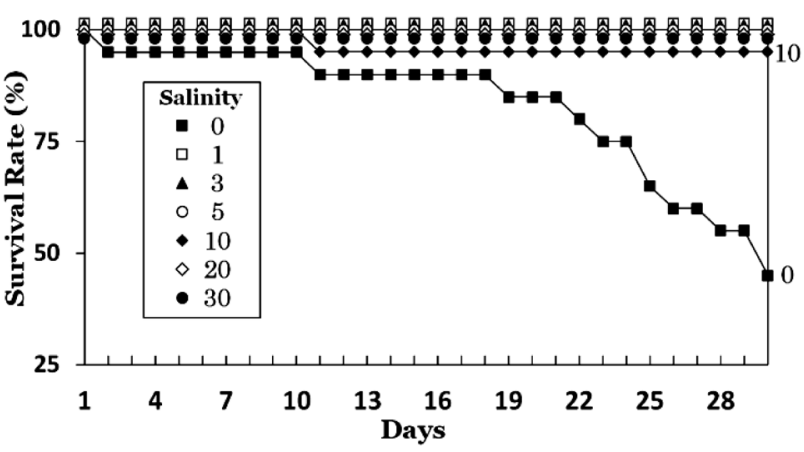

Fig. 6. Results of salinity tolerance experiments under seven different salinity conditions during 30 days $(n=20$ in each condition).

底質であったが，ライン 3 より上流からはシルト・クレイ 分が約 30〜 50\%程度となることもあり，比較的泥分に富 む底質環境となっていた．多摩川の底質のシルト・クレイ 分は, ライン 3 より下流の地点では $30 \%$ 以下と比較的低 い值となったが，ライン 4 よりも上流では，60\%以上のシ ルト・クレイ分を含む地点もみられ，軟泥質の底質となっ ていた，多摩川の塩分は，夏期調査時には塩分 $10 \sim 21$, 秋期調查時には塩分 8〜13 の範囲にあり，いずれも上流に 設定したラインで低くなる傾向がみられた。一方，可動堰 により河川水の影響が著しく制限されている江戸川では, 調査ライン，あるいは調査時期別にみても塩分の変動はほ とんどみられなかった。

\section{塩分耐性実験}

30 日間の実験期間では, 塩分 1 30 試験区における個 体の死亡率は極めて低く, 実験開始 11 日目に塩分 10 試験 区において 1 個体の死亡が確認されるにとどまった（Fig. 6).それに対して, 淡水の試験区では, 実験開始 17 日目 までは 2 個体の死亡がみられるのみであったが，それ以降 は斃死率が高くなり，最終的には供試個体 20 個体のうち 半数を上回る 11 個体が獘死した. しかしながら, 淡水の
試験区においても 30 日間の実験期間では供試個体が全滅 することはなかった。このように，実験全体を通してがタ ヅキが強い低塩分耐性を示す結果が得られており，本種が 広塩性種であることが明らかとなった。

\section{考察}

\section{ガタヅキの繁殖生態}

ガタヅキの繁殖生態について同属近縁種との比較検討を 行った（Table 2).

卵胎生と雌雄同体は，既知のガンジキ属の種におおむね 共通する繁殖様式である。これに関してガタヅキが同様の 卵胎生種であることが, 本研究の結果より明らかとなっ た。野外におけるガタッ゙キの卵・胎貝保有率には夏場の繁 殖盛期と冬場の繁殖休止期が明瞭にみられ，特に $6 \sim 9$ 月 にかけての卵・胎貝保有率は $90 \%$ 前後と極めて高い值で 推移した。これは, 本研究で成貝とした個体に極端な性比 の偏りが生じていることを示しており，ガタヅキが同属他 種と同様の雌雄同体の可能性があることを示唆している.

ガタッ゙キの体内で保育される $\mathrm{D}$ 型幼生は, 最大でも殼 長 $0.3 \mathrm{~mm}$ 程度であり, 幼生はこれを境として親貝から外 部に放出されるものと推定される。また, 複数の飼育実験 下で放出直後と考えられる殼長 $0.3 \mathrm{~mm}$ 程度の稚貝が飼育 容器内で確認されており，それらの稚貝には親貝と同様に 足で容器内をほふく移動する様子が認められたことから, ガタッ゙キの幼生は放出後に浮遊期をほとんど経ることなく 底生生活を開始する直達発生型であるものと結論付けられ る. 同属他種で知られている放出前後の幼生サイズは, 共 生対象を持つ種であるガンッ゙キや A. bifurca, A. crassiformis が 0.12 0.16 mm の範囲にあるのに対し, 自由生活種であ る A. semen は $0.2 \sim 0.5 \mathrm{~mm}$ と比較的大型の幼生を生産する 傾向がある. また, 共生種である A. bifurca や A. crassiformis は幼生が浮遊期を持つのに対し, A. semen の生活史には浮 
Table 2. Ecological characteristics of Arthritica species.

\begin{tabular}{|c|c|c|c|c|c|c|c|}
\hline \multirow{2}{*}{$\frac{\text { Species }}{\text { Arthritica reikoae }^{1}}$} & \multirow{2}{*}{$\begin{array}{r}\text { Life style } \\
\text { Free living }\end{array}$} & \multicolumn{2}{|c|}{ Reproductive strategy } & \multirow{2}{*}{$\frac{\text { Larval form }}{\text { Benthic }}$} & \multirow{2}{*}{$\begin{array}{l}\text { Size of larvae } \\
\text { ca. } 0.3 \mathrm{~mm}\end{array}$} & \multirow{2}{*}{$\begin{array}{l}\text { Brood size } \\
\text { Ave. } 13.0\end{array}$} & \multirow{2}{*}{$\begin{array}{c}\text { Breeding cycle } \\
\text { ca. } 20 \text { days }\end{array}$} \\
\hline & & Ovoviviparous & Hermaphroditic? & & & & \\
\hline A. semen ${ }^{2}$ & Free living & Ovoviviparous & Hermaphroditic & Benthic & $0.2-0.5 \mathrm{~mm}$ & - & - \\
\hline A. bifurca ${ }^{3,4}$ & Commensal & Ovoviviparous & Hermaphroditic & Planktonic & Ave. $0.12 \mathrm{~mm}$ & $5^{-5,016}$ & 11-21 days \\
\hline A. crassiformis ${ }^{3,4}$ & Commensal & Ovoviviparous & Hermaphroditic & Planktonic & Ave. $0.15 \mathrm{~mm}$ & $245-3,120$ & 8.5-20 days \\
\hline A. japonica ${ }^{5}$ & Commensal & Ovoviviparous & Hermaphroditic & - & ca. $0.16 \mathrm{~mm}$ & - & - \\
\hline A. hulmei ${ }^{3}$ & Commensal & Ovoviviparous & - & - & - & - & - \\
\hline
\end{tabular}

1, present study; 2, Wells and Threlfall (1982b); 3, Ponder (1965); 4, Chanley and Chanley (1980); 5, Lützen and Takahashi (2003)

遊幼生期が存在しないことが知られている.ガタヅキは野 外での生息状況や飼育下での繁殖からみて A. semen と同 様の自由生活種とみなされる。このような比較的大型の直 達発生型幼生の生産は, ガンジキ属の中での自由生活種に 共通する繁殖様式といえる. 自由生活種の幼生は分散能が 低く, 親貝近辺の生息適地に直接加入できるほか, 幼生自 体も大型なので, 放出直後の幼生の生残率は比較的高いも のと推定される。これは, 1 回に多くても数 10 個体の幼 生しか保育しないガタッ゙キの生存戦略として, 幼生の親個 体群への同所的加入成功率を高めるという点で有利であ る. Furota et al. (2002) は, プランクトン発生をするウミ ニナBatillaria multiformis と直達発生であるホソウミニナ B. cumingi について, 東京湾奥の隔離された干潟環境にお けるそれぞれの個体群動態を比較し, 親の生息場で同所的 な再生産が可能な直達発生は, 孤立した環境での個体群サ イズの増加と維持に有利に働くことを指摘している.今回 調査されたガタッ゙キの生息地は, 江戸川放水路, 多摩川河 口, 大森と湾内に分離的に点在しており, 中でも大森の造 成海域は面積も小さく（約 $6.8 \mathrm{ha｝ \text {) 周囲を夏場になると貧 }}$ 酸素化によりベントスがほとんど確認されない運河に囲ま れている（中瀬ら 2008; 中瀬ら 2010）ことから環境は際 立って孤立的である. しかし, そのような環境下でも多数 のガタヅキが確認される場合があり, 浮遊幼生期を欠くこ とで可能となる親貝近辺への直接的な加入は, ホソウミニ ナの例と同様に隔離された環境において一旦個体群が形成 された後の再生産に適応的であることが言える.しかし， 分散能が乏しい繁殖戦略は, 生息適地が豪雨による土砂流 出などの環境攪乱によって個体群が大きなダメージを受け た場合, 個体群規模が激減さらには消滅するという危険性 も有している. 大森のベントスモニタリング調査では, 2011 年 2 月の干潟修復工事を境にガタッ゙キの生息数が減 少し, その後 1 年間は個体数の回復はみられていない（未 発表)。しかし, 江戸川や多摩川のように, 夏場の繁殖盛 期に群集の一部が残されているような状況では, 直後約 3 か月間の内に大幅な生息密度の増加が確認されている (Fig. 5). 幼生の分散能が低いガタッ゙キは, 生息地に母集 団が存在する状況では同所的加入により速やかな個体群の 増大が可能となる一方, 個体群が極めて大きなダメージを 受けた際には他の生息地からの加入が見込めないために回
復が遅れるものと考えられる.

繁殖休止期にあたるガタヅキを夏場の水温を想定した $28^{\circ} \mathrm{C}$ の恒温条件で飼育した結果, 実験供試個体の $47.3 \%$ $(n=497)$ で卵や胎貝の保育といった繁殖活動が確認され た。この結果は, 野外での繁殖活動の消長と周辺海水温と の相関が高かった $(r=0.928)$ (Fig. 3）ことを併せて, 夏 場の繁殖期が季節的な水温の上昇により引き起こされてい ることを強く示唆している. 飼育下の個体では, 卵保育個 体が確認されてから約 20 日間で D 型幼生を保育する個体 が出現し, この D 型幼生を保有する個体の多くが体内に 新たな卵を保有していた。このことは, ガタッ゙キが約 20 日間周期で連続的に繰り返し繁殖するという, 比較的短い 繁殖周期を有していることを示唆している. 近縁種の $A$. crassiformis では幼生放出から数えて 11〜21日, A. bifurca では 8.5〜20日の間隔をおいて次の幼生を放出するとの報 告があり（Table 2)，これを繁殖周期とすると，ガタッ゙キ の繁殖周期は同属他種とも比較的類似している.

\section{河口における分布状況}

河口域を対象とした分布調査では, 特に繁殖期後の秋期 調査において，ガタッ゙キが高密度で集中するという生息特 性が認められた（Fig. 5). ガタッ゙キと似た直達発生の繁殖 生態を持つA. semenでは, オーストラリア南西の Peel Inlet において $1 \mathrm{~m}^{2}$ あたりの生息密度が 40,000 個体を超え る場合もあり（Wells \& Threlfall 1982a），ガタッ゙キに関し てもその繁殖特性の結果として高密度の生息状況が生じた ものと考えられる.また, 本調査で確認された $100 \mathrm{~cm}^{2}$ あ たり 1,500 個体（1 $\mathrm{m}^{2}$ 換算では 150,000 個体）を上まわる ような極めて高密度での生息状況は, 他の二枚貝類の成貝 ではほとんど例のないことであるが，これに関しては上述 の繁殖生態もさることながら, ガタッ゙キそれ自体が微小で あるために成熟までの期間が短く, かつ個体間の干渉や資 源をめぐる競争が生じにくいことも一つの要因となってい ると推測される.

本邦におけるガタッ゙キの分布は, 河口域あるいは汽水湖 といった沿岸の汽水域に多く知られている（日本ベントス 学会 2012, p. 154).このような環境に生息するガタッ゙キ は, 潮汐変動や降雨に関係して大きな塩分変化にさらされ る. 今回の塩分耐性実験では, ガタッ゙キは純淡水を除く広 
範囲の塩分条件下において生存可能な広塩性種であること が示された．これは，ガタッ゙キが汽水域特有の塩分変化の 中にあっても生息可能な種であり，本種が汽水環境におい ても個体群を維持することが可能な汽水性種であることを 明確に示している，河口域調査時の塩分濃度は, 瞬間值で はあるが，いずれも塩分耐性実験により本種の生存が可能 とされる範囲内にある（Table 1). しかし, ガタッ゙キの実 際の分布状況には明暸な偏在傾向が認められている（Fig. 5). 多摩川では上流に向かうに従い, 江戸川では可動堰付 近において塩分が低下するというょうに，両河川には緩や かな塩分勾配が存在する. しかし, 塩分耐性の実験結果も 併せて, こうした塩分の空間変異から本種の生息が両河川 ともに河口から $1.5 \sim 2 \mathrm{~km}$ を境に急激に変化する点を説明 することは難しい，多摩川におけるガタッ゙キの生息密度 は, シルト・クレイ分が顕著に高くなるライン 4 から上流 において著しい減少傾向がみられる（Table 1)，そのため, 本種は軟泥質の底質環境を好まないものと考えられる。一 方江戸川では, 可動堰に近い上流の地点において生息密度 が高まる傾向がみられた. 可動堰付近は河口と比較して奥 まった環境で, ヨシ群落といった構造物が発達する. 直達 発生である本種にとって, 環境攪乱からの避難場所の存在 は重要であると考えられる. そのため, 江戸川では可動堰 開放時や平時における擋乱の影響を緩和するヨシ群落が存 在し, また海域からの波浪等の影響が少ない可動堰付近に 分布が集中したものと推測される.

\section{外来種である可能性}

日本ベントス学会 (2012, p. 154) はガタッ゙キに関して, 近年まで発見例がなく, 環境悪化の著しい東京湾奥で増殖 したことから外来種の疑いがあると指摘している．近年ま で確認されなかったことに関しては, 本種の生息する河口 干潟を対象としたベントス群集調査がこれまであまり行わ れてこなかった点や, 本種が微小であり通常の $1 \mathrm{~mm}$ 目の 篩を用いた調査では採捕しにくいこと，夏場に増殖するた め従来の春から初夏にかけてのベントス調査では発見が難 しいこと，そして同一河川内であっても分布が偏ることな どから本種の発見は容易ではないと考えられる。したがっ て, 近年発見例が増えたとしても, 過去に本種の生息がな かったかどうかは明らかではなく, 現時点では本種を外来 種であるとする根拠には乏しい. 大森海域の造成は 2004 年に完了し, 干潟面の安定後約 5 年間がタッ゙キの生息が確 認されなかったが, 2009 年になると多数の個体が出現す るようになった。このことは, 本種が直達発生であって も，隔離された汽水域にある小さな干潟に自然分散により 広がる可能性があることを示唆している。また，岡本 （2012）は本種の生息を東京湾内の小櫃川河口や千葉県外 房の小規模河川などから報告している. そのため, 本種が 各地の小規模な生息場間で交流を持ちながら, メ夕個体群 として存在していた可能性は十分に考えられる.これらの
ことから，ガタヅキは外来種の可能性もあるが，現状では 湾内での在来の個体群を形成していた可能性も高いため, 今の時点では本種を外来種であると判断することは難し い.

\section{ま と め}

野外調査の結果から, 夏場の繁殖期に $90 \%$ の成貝が雌 性として繁殖に加わっていることから, ガタッ゙キは同属他 種と同様の雌雄同体であると推定された。親貝が一度に保 育する胎貝数は $13.0 \pm 5.7$ 個体（Mean \pm S.D.; $n=148 ） と$ 少数であり, 放出間際の幼生サイズは殼長 $0.3 \mathrm{~mm}$ 程度と 同属他種の中でも比較的大型であった．冬場の繁殖休止期 の個体を $28^{\circ} \mathrm{C}$ の加温条件下で飼育したところ, 夏場と同 様の繁殖活動がみられたことから, ガタッ゙キの繁殖期は季 節的な水温の上昇に誘導されるものとみなされた。 また, 飼育実験では本種の繰り返し行われる繁殖の周期は約 20 日間であった。野外でのガタッ゙キの生息密度は, 繁殖期後 に大きく増加し, 多摩川では最大で $100 \mathrm{~cm}^{2}$ あたり 1,500 個体を超えるような高密度での生息が認められた。ガタッ゙ キは大型の幼生を生産する卵胎生種であるため, 比較的幼 生の加入成功率が高く, また幼生の分散能が低いことから 親と同所での高密度の生息状況が生じやすいものと考えら れる. 塩分耐性実験の結果, ガタッ゙キは広塩性であり, 環 境の変化が激しい汽水域においても個体群の維持が可能で ある. 河口域におけるガタッ゙キの分布には偏在傾向がみら れるが,これに関しては底質性状の変化や攪乱からの避難 場所の有無が本種の生息に影響していることが推測され る. 近年になって確認報告が増えたことから，ガタッ゙キは 外来種ではないかとの疑いもあるが, 本種は微小なため発 見が容易ではないなどから, 現時点では在来の個体群であ る可能性も否定できない.

謝辞 : 岡山大学農学部の福田宏准教授には, 大森のベントスモ ニタリング調査で不明種として出現したガタッ゙キを同定していた だき，本研究に有益となる知見・資料を多数紹介していただきま した.また，岡本正豊様には貴重な資料・サンプル等を提供して いただきました。ここに深く御礼申し上げます．東海大学海洋学 部海洋生物学科の田中彰教授には電子顕微鏡撮影時にご指導をい ただきました。同研究科の赤川泉教授には英文等の表現に有益な 助言をいただきました．東海大学海洋学部海洋生物学科木村研究 室の江澤増美氏, 長沼美穂氏にはサンプリングとその後のソー ティングに多大な協力をいただきました。ここに感謝申し上げま す。また，本論の取りまとめに有益なご指摘，コメント等をいた だいた 2 名のレフェリーに感謝申し上げます.

\section{引用文献}

Chanley, P. and M. Chanley 1980. Reproductive biology of Arthritica crassiformis and A. bifurca, two commensal bivalve molluscs (Leptonacea). New Zealand Journal of Marine and Freshwater Research, 14: 31-43. 
Furota, T., T. Sunobe and S. Arita 2002. Contrasting population status between the planktonic and direct-developing Batillariid snails Batillaria multiformis (Lischke) and B. cumingi (Crosse) on an isolated tidal flat in Tokyo Bay. Venus: journal of the Malacological Society of Japan, 61: 15-23.

環境省 2012. 第 4 次レッドリスト. http://www.biodic.go.jp/rdb/ rdb_f.html

Lützen, J. and T. Takahashi 2003. Arthritica japonica, sp. nov. (Bivalvia: Galeommatoidea: Leptonidae), a commensal with the pinnotherid crab Xenophthalmus pinnotheroides White, 1846. The Yuriyagai, 9: $11-19$.

中瀬浩太 - 金山 進 - 木村賢史 ・山本英司 2008. 都市内湾域に再 生された浅場・干潟の環境モニタリング. 海洋開発論文集, 24 : 765-770.

中瀬浩太 - 金山 進 - 木村賢史 ·上野淳一 ・石橋克己 2010. 都市 内湾域の人工干潟水域における水質環境と生物に関するモ二タ リング．海洋開発論文集，26: 729-734.

日本ベントス学会 (編) 2012. 干潟の絶滅危惧動物図鑑一海岸べ ントスのレッドデータブック, 東海大学出版会, 秦野, $285 \mathrm{pp}$.
岡本正豊 2012. 微小二枚貝コハギガイの千葉県 4 河口における棲 息状況, 岡本正豊, 柏, $44 \mathrm{pp}$.

Ponder, W. 1965. The biology of the genus Arthritica. Transactions of the Royal Society of New Zealand Zoology, 6: 75-86.

佐藤慎一 一多留聖典・福田 宏・多々良有紀 2010. 2009 年度軟 体動物多様性学会夏季例会（南三陸）報告. Molluscan Diversity, 1: 54-60.

Suzuki, T. and S. Kosuge 2010. Description of a new species of Lasaea reikoae Suzuki \& Kosuge n. sp. from estuary area of Edogawa River, Tokyo Bay (Bivalvia, Erycinidae). Bulletin of the Institute of Malacology Tokyo, 3: 147-148.

Wells, F. E. and T. J. Threlfall 1982a. Density fluctuations, growth and dry tissue production of Hydrococcus brazieri (Tenison Woods, 1876) and Arthritica semen (Menke, 1843) in Peel Inlet, Western Australia. Journal of Molluscan Studies, 48: 310-320.

Wells, F. E. and T. J. Threlfall 1982b. Reproductive strategies of Hydrococcus brazieri (Tenison Woods, 1876) and Arthritica semen (Menke, 1843) in Peel Inlet, Western Australia. Journal of the Malacological Society of Australia, 5: 157-166. 